\title{
Students' Creative e-Portfolios: Using Android Cell Phone Cameras for Inventive Beauty Photography
}

\author{
Setya Chendra Wibawa ${ }^{a, 1}$, Beth Clark-Gareca ${ }^{\text {b,2 }}$ \\ ${ }^{a}$ Creative Multimedia Design Laboratory, Home Economics Department \\ Faculty of Engineering, The State University of Surabaya, Indonesia \\ ${ }^{\mathrm{b}}$ Steinhardt School of Culture Education and Human Development, New York University \\ 1'bowolee@yahoo.com, ${ }^{2}$ garecabeth@yahoo.com,bc210@nyu.edu
}

\begin{abstract}
In the $21^{\text {st }}$ century, knowledge society, creativity and innovation in the educational context are becoming increasingly important, especially for the ASEAN Vocational Education and Training (VET) community. Creative portfolio is one way in which this creativity can be captured. Creative portfolios often consist of elements from the field of home economics, including fashion, culinary science, and beauty. These elements require students to think creatively for instance by the use of their cell phone as a camera. Though they have never considered using their cell phone in this way, such projects can be very valuable for students' learning. This research explores the use of camera features on the cell phone to capture subjects in the creation of Javanese traditional wedding make up using the traditional costumes of each area and to document them using a cell phone with video camera features. These videos were then edited using Adobe Premiere and they can be viewed as pdf files. Findings of this research suggested that the students were eager to have creative video portfolios using many different techniques. Out of this project, the mini Glidecam was implemented to stabilize the video to eliminate shaking when still recording. This research therefore contributed to broaden creative video portfolio techniques and it will help people who are interested in developing a creative video portfolio in simple yet professional ways.
\end{abstract}

Index Terms - camera cell phone, creative portfolio

\section{Introduction}

In the past, portfolios were collections of work stored in binders, file folders, or boxes. Today, computers are used as an effective tool for developing and storing portfolios given their ability to store and process large quantities of content and because they can effectively support and guide the portfolio process. There are many advantages to using electronic portfolios (e-portofolios). Students can easily integrate multimedia materials, allowing them to use a variety of tools to demonstrate and develop understanding. Students become easy to share with peers, teachers, parents and others. In addition, e-portofolios let students and others provide feedback through a single electronic container. At the same time, the e-portfolios provide remote access for students' completion of homework or when learning at a distance, for teachers for review and assessment purposes, and for parents to improve communication [3].

Guo, 2007, has identified several benefits and problems of e-portfolio assessment as tabulated in Table 1 [5].

In this paper, the authors explore the usefulness of students-created short videos to enhance the quality of e- portfolios in their fields. The videos can be either recording their projects, demonstrating make up, capturing a relevant activity, or describing a theory using simulations. The authors have collected videos from cosmetology students over a year. As these videos have become part of repository, they are made available on public video-sharing website like youtube.com.

Table 1 Benefits and problems of e-portfolio assessment

\begin{tabular}{|l|l|}
\hline \multicolumn{1}{|c|}{ POTENTIAL BENEFIT } & \multicolumn{1}{|c|}{ PROBLEMS/CONSTRAINTS } \\
\hline $\begin{array}{l}\text { Support students' } \\
\text { development as a reflective } \\
\text { practitioner }\end{array}$ & $\begin{array}{l}\text { Instructors lack the time to } \\
\text { work on this extra workload }\end{array}$ \\
\hline $\begin{array}{l}\text { Provide a mechanism for } \\
\text { assessment in both } \\
\text { formative and summative } \\
\text { way }\end{array}$ & $\begin{array}{l}\text { Adapting to the current } \\
\text { curriculum, insufficient } \\
\text { pedagogical planning }\end{array}$ \\
\hline $\begin{array}{l}\text { Bridge personal learning space } \\
\text { and institutional learning } \\
\text { management system }\end{array}$ & $\begin{array}{l}\text { Articulation of standards to } \\
\text { apply intellectual property and } \\
\text { privacy issues }\end{array}$ \\
\hline $\begin{array}{l}\text { Provide coherent and richer } \\
\text { content student learning } \\
\text { records for university } \\
\text { education }\end{array}$ & $\begin{array}{l}\text { Effort in organizing, maintaining, } \\
\text { and authorizing the content. } \\
\text { Managing access for future } \\
\text { academic and industry employers }\end{array}$ \\
\hline $\begin{array}{l}\text { Promote sharing and } \\
\text { collaborative learning }\end{array}$ & $\begin{array}{l}\text { Information exchange with } \\
\text { departmental online course and } \\
\text { discussion forum }\end{array}$ \\
\hline
\end{tabular}

\section{Literature Review}

A variety of definitions of portfolios have been found in the literature consulted for this study. Electronic portfolios traditionally have been defined as an organized collection of digital and/or analog artifacts and reflective statements that demonstrate a learner's intellectual development over time [2].

Hofer and Swan (2005) note that the research literature on the subject of student created videos are limited and should be explored at a college level [6]. Greene and Crespi (2012) identified that students enjoyed student created, video projects and saw the projects as both entertaining and educational. The paper investigates the perceived value of college student created videos as a tool for enhancing the student learning experience. Two different business courses are examined: one of the courses is an undergraduate 
accounting course and the other is an undergraduate marketing course, both in a school of business in a comprehensive state university in the northeast. In the marketing course, students are required to create videos as part of their grade assessment; in the accounting class, creating videos is an optional extra credit assignment. Qualitative research was conducted by asking students to write brief responses describing their experience with creating videos. Descriptive statistics were gathered in an effort to assess student satisfaction and appreciation for the video creation experience. The results of the research suggest that students appreciate the video experience; they find it relevant and entertaining. They also report that it helps reinforce concepts they have been exposed to in class [4].

Schuck and Kearney (2004) add that the videos encourage student engagement and Parker (2002) report how videos support student creativity. Burn et al. (2001) explain how student videos accommodate students with different learning styles and abilities.

The author explains the creative video portfolio using the power of short film about collaboration of some creative industries specially makeup artist, fashion designer, photographer also videographer to reduce budget [13].

\section{Creativity}

Amabile, Head of the Entrepreneurial Management Unit at the Harvard Business School, has provided the field with one of the most simple and yet comprehensive frameworks for the topic. As depicted in Figure 1, creativity arises through the confluence of the following three components:

- Knowledge, all the relevant understanding an individual brings to bear on a creative effort

- Creative Thinking, it relates to how people approach problems and depends on personality and thinking/working style

- Motivation, motivation is generally accepted as key to creative production and the most important are intrinsic passion and interest in the work itself [1]

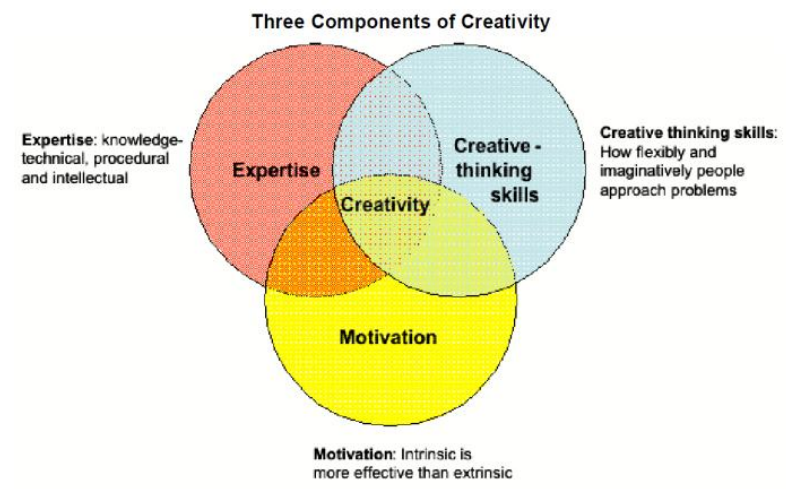

Figure 1. Three components of creativity.

\section{Data Collection}

The steps in developing a creative video portfolio, a number of researchers have identified specific steps to follow in developing a portfolio namely [10]:

- Determine the outline of the portfolio by drawing a schematic representation of the outline, discussing the process with peers, mentors or other specialists to get an idea of what the portfolio should contain.

- Identify the goal of the portfolio create some a note like a storyboard for the detail execution maybe for the time using

- Determine the properties, preparing the accessories, equipment, location, model for the need of making of creative video portfolio. The need of properties can be known by the storyboard

- Create a video document by using a note (storyboard), following the narration until step how taking video by cell phone camera, here all materials and completed assignments can be kept until the final selection for the presentation portfolio is made

- Create a composition by software adobe premiere using a note (storyboard), and note at the location during taking video, following the narration until step how taking video by camera

- The working portfolio can serve as the document center like MP4 video format, while the presentation portfolio, which is meticulously and professionally compiled, can serve to testify to the skills and abilities during presentations.

\section{Steps to Editing using Adobe Premiere}

a. Capture: Hook the digital video camera up to a fire wire cord. Open Adobe Premiere CS 6 as shown in Figure 2. It should ask to open a new movie, which is a profile, click the capture tab to open up the capture window. Use the device controls and the capture button to capture the video. It should stop playing when stop the capture or when the tape ends. Time code gaps will not be recorded, or copy the video file from cell phone to hard-disk.

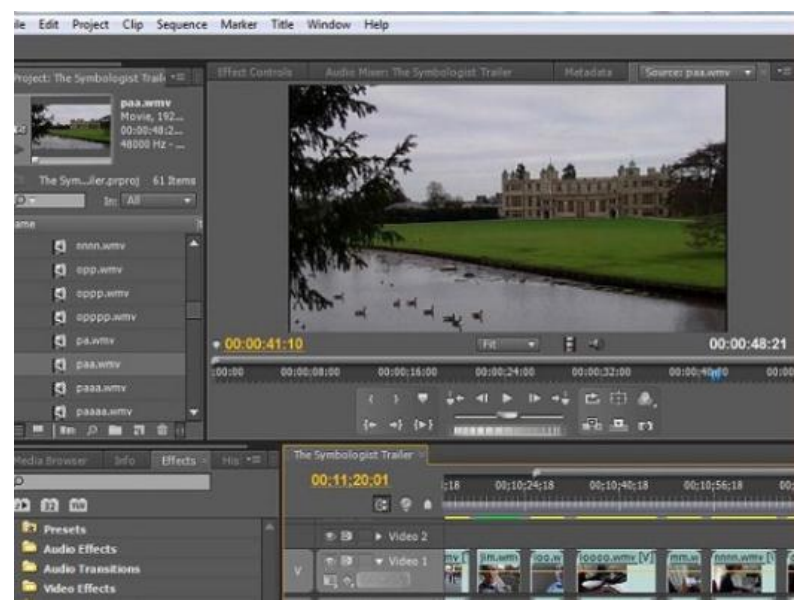

Figure 2. Adobe premiere view.

b. Edit: Click on the edit tab to open the editing workspace. Trim, cut and move your clips as like. Get rid of undesired footage and order the clips in a sensible way. Add music by adding the song to audio 2 to have the camera audio two, or go to one of the upper bar options, and go to clip options and go to audio and go to render and replace and in add media, delete the audio and say YES to deleting and drag the audio to audio. 
c. Effects: Put in transitions and effects by going to the effects tab. Go in to transitions and drag the transitions to between the scenes.

d. DVD: Use the DVD window to add main menu, scene and stop markers. You can also choose DVD templates and customize them Burn the DVD by clicking Burn. Or, the file will become MP4 video file. Figure 3 gives a screenshot of part of a video file.

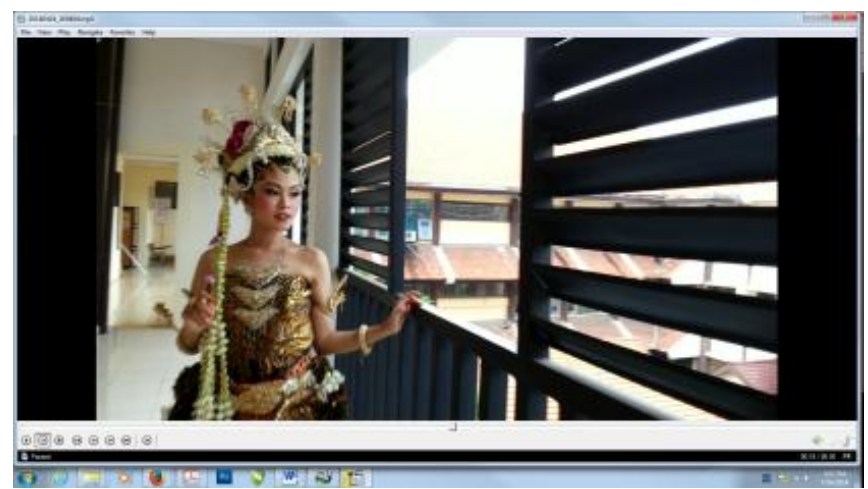

Figure 3.(a). Part of scene.

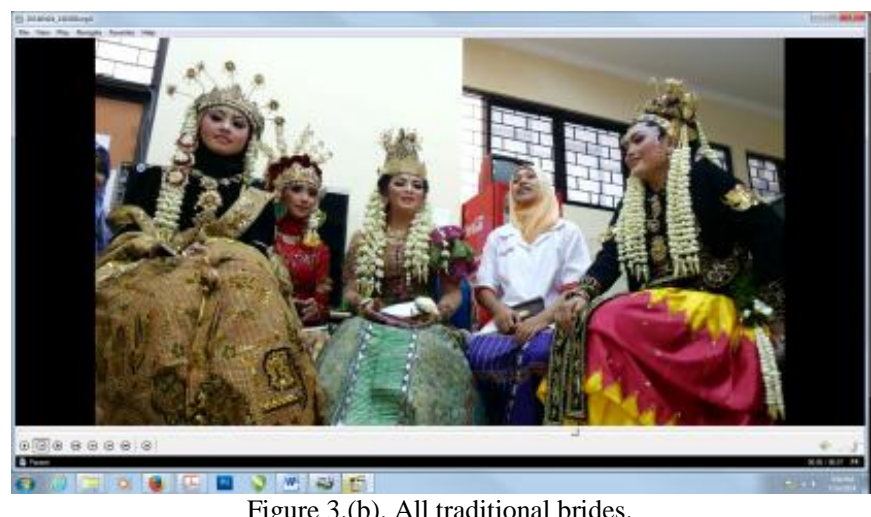

The video files as a result can be collaborated with other materials such document word or excel, presentation, music, photography in one of view using adobe acrobat. Figure 4 demonstrates a video file shown in Adobe Acrobat.

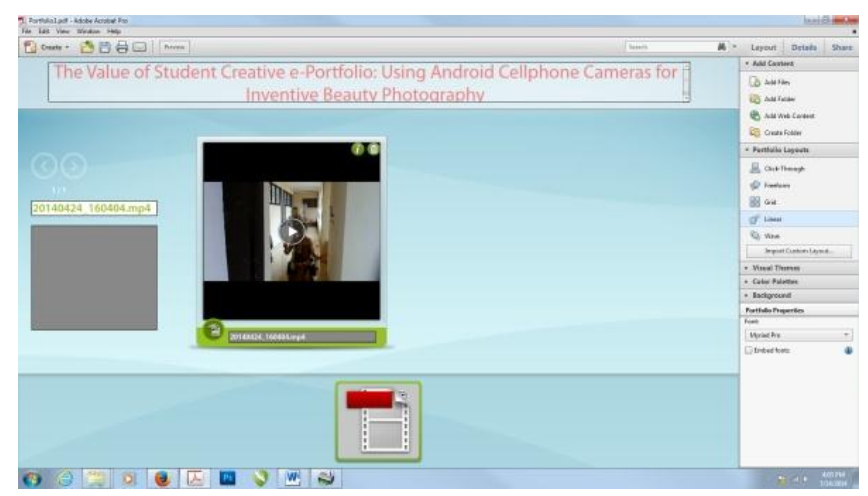

Figure 4. Video file in Adobe Acrobat.

In order to evaluate video portfolio a simple questionnaire as tabulated in Table 2 was given students' respondents. The respondents rated every question with a Likert scale of 1 to $4 ; 1$ strongly disagree, 2 disagree, 3 agree, 4 strongly agree.

\section{Results and Discussion}

Twenty seven students' respondents have participated in the questionnaire. There are 9 questions as shown in Table 2. Every respondent rated every question in Table 2 as tabulated in Table 3.

Table 2 List of questions given to students' respondents

\begin{tabular}{cl}
\hline No & \multicolumn{1}{c}{ Description about creative video portfolio } \\
\hline 1 & $\begin{array}{l}\text { Creating video using a cell phone is powerful in limited } \\
\text { equipment }\end{array}$ \\
\hline 2 & Creating videos in each field are an enjoyable experience \\
\hline 3 & Creating videos is a useful experience \\
\hline 4 & Creating videos is an interesting experience \\
\hline 5 & The video project was the most useful projects in class \\
\hline 6 & Creating videos enhances learning content \\
\hline 7 & Creating videos will enhance learning in future classes \\
\hline 8 & Creating videos need creativity in contents \\
\hline 9 & Creating videos in each field are an important exercise
\end{tabular}

Table 3 Scale of every question rated by students' respondents

\begin{tabular}{|c|c|c|c|c|c|c|c|c|c|}
\hline \multirow{2}{*}{ Respondent } & \multicolumn{9}{|c|}{ Descriptive Statistics about value of creative video portfolio } \\
\cline { 2 - 11 } & $\mathbf{1}$ & $\mathbf{2}$ & $\mathbf{3}$ & $\mathbf{4}$ & $\mathbf{5}$ & $\mathbf{6}$ & $\mathbf{7}$ & $\mathbf{8}$ & $\mathbf{9}$ \\
\hline 1. & 4 & 3 & 3 & 3 & 4 & 3 & 2 & 4 & 3 \\
\hline 2. & 4 & 4 & 3 & 3 & 3 & 4 & 3 & 3 & 3 \\
\hline 3. & 3 & 4 & 3 & 3 & 4 & 4 & 3 & 4 & 3 \\
\hline 4. & 4 & 3 & 3 & 3 & 3 & 4 & 3 & 4 & 4 \\
\hline 5. & 4 & 4 & 3 & 2 & 4 & 4 & 3 & 4 & 4 \\
\hline 6. & 3 & 3 & 3 & 4 & 3 & 3 & 3 & 3 & 3 \\
\hline 7. & 4 & 4 & 4 & 4 & 4 & 4 & 4 & 4 & 4 \\
\hline 8. & 3 & 3 & 3 & 3 & 4 & 3 & 3 & 4 & 4 \\
\hline 9. & 3 & 3 & 3 & 3 & 3 & 4 & 2 & 3 & 2 \\
\hline 10. & 4 & 4 & 3 & 3 & 4 & 4 & 3 & 4 & 3 \\
\hline 11. & 3 & 3 & 3 & 3 & 4 & 4 & 3 & 4 & 3 \\
\hline 12. & 4 & 4 & 3 & 4 & 4 & 4 & 4 & 4 & 4 \\
\hline 13. & 3 & 3 & 4 & 4 & 4 & 4 & 3 & 4 & 3 \\
\hline 14. & 4 & 3 & 3 & 3 & 4 & 3 & 4 & 4 & 3 \\
\hline 15. & 4 & 3 & 3 & 3 & 3 & 3 & 2 & 4 & 2 \\
\hline 16. & 4 & 3 & 3 & 3 & 3 & 4 & 3 & 3 & 3 \\
\hline 17. & 3 & 3 & 3 & 3 & 4 & 3 & 3 & 4 & 4 \\
\hline 18. & 4 & 3 & 3 & 3 & 4 & 3 & 3 & 3 & 2 \\
\hline 19. & 4 & 3 & 3 & 3 & 3 & 3 & 3 & 4 & 3 \\
\hline 20. & 4 & 3 & 3 & 3 & 4 & 3 & 3 & 3 & 3 \\
\hline 21. & 3 & 3 & 3 & 3 & 3 & 3 & 2 & 4 & 3 \\
\hline 22. & 4 & 3 & 3 & 3 & 3 & 4 & 3 & 3 & 2 \\
\hline 23. & 4 & 3 & 3 & 3 & 4 & 3 & 2 & 4 & 2 \\
\hline 24. & 4 & 3 & 3 & 4 & 3 & 3 & 3 & 4 & 3 \\
\hline 25. & 4 & 3 & 3 & 3 & 3 & 4 & 4 & 4 & 4 \\
\hline 26. & 4 & 3 & 3 & 3 & 3 & 3 & 3 & 4 & 3 \\
\hline 27. & 4 & 3 & 3 & 3 & 3 & 3 & 3 & 4 & 2 \\
\hline Number & $\mathbf{1 0 0}$ & $\mathbf{8 7}$ & $\mathbf{8 3}$ & $\mathbf{8 5}$ & $\mathbf{9 5}$ & $\mathbf{9 4}$ & $\mathbf{8 0}$ & $\mathbf{1 0 1}$ & $\mathbf{8 2}$ \\
\hline Average & $\mathbf{3 . 7 0}$ & $\mathbf{3 . 2 2}$ & $\mathbf{3 . 0 7}$ & $\mathbf{3 . 1 5}$ & $\mathbf{3 . 5 1}$ & $\mathbf{3 . 4 8}$ & $\mathbf{2 . 9 6}$ & $\mathbf{3 . 7 4}$ & $\mathbf{3 . 0 3}$ \\
\hline & & & $\mathbf{A v e r a g e}$ all of aspect $\mathbf{3 . 3 1}$ & & & \\
\hline
\end{tabular}

From Table 3, most of the respondents strongly agree that a cellular phone in its limitation is a powerful tool in creating videos. In addition, creativity is needed in contents of the videos. Therefore, the videos are most useful project in class. All these findings are reflected by scales of higher than 3.5 for questions no. 1,8 , and 5 .

Most of respondents agree that creating videos are enjoyable, useful, and interesting experiences and an important exercise. Moreover, the videos enhance learning contents and learning in future classes. These are shown by scales in the range of 2.96 to 3.48 .

\section{Conclusions and Implication (in Educational Work)}

We have shown that a cellular phone is a powerful tool in creating videos by the students. In addition, the students' creativity is needed in making contents of the videos. 
Moreover, the students considered that creating videos are enjoyable, useful, and interesting experiences and an important exercise. Although the instructors expected students to be familiar with video equipment and editing software, this expertise is not as ubiquitous as originally hypothesized. Those students, who were not comfortable with video equipment and editing software, were more likely to feel frustrated and less likely to enjoy the project. This issue will be addressed in future classes by devoting at least one class or portion thereof to video creation and video editing and by requiring students to complete a mini exercise in class in which they will utilize these tools early in the semester.

\section{References}

[1] K. Adams, The sources of innovation and creativity, National Center on Education and the Economy, Paper Commission, 2006.

[2] H. Barrett, "Electronic Portfolios = Multimedia Development + Portfolio Development: The Electronic Portfolio Development Process," in B, Cambridge (ed.), Electronic Portfolios, American Association for Higher Education, pp. 110-116, 2001.

[3] F. Costa and M. Laranjeiro, ePortfolio in Education: Practices and Reflections, ISBN: 978-989-95341-3-1, Portugal, 2008.

[4] H. Greene, Crespi, and Cheryl, "The value of student created videos in the college classroom - An Exploratory Study In Marketing and Accounting," International Journal of Arts and Sciences, pp. 273283, 2012.

[5] Z. Guo, Connecting Electronics Portfolio and Leaner Models, Thesis, Department of Computer Science University of Saskatchewan Saskatoon, 2007.

[6] M. Hofer and K. Swings-Swan, "Digital movie making-the harmonization of technology, pedagogy and content," International Journal of Technology in Teaching and Learning, vol. 1, no. 2, p. 102110, 2005.

[7] M. Kearney and S. Schuck, Students in the director's seat: Teaching and learning with student-generated video. In P. Kommers and G. Richards (Eds.), Proceedings of the 2005 World Conference on Educational Multimedia, Hypermedia and Telecommunications, pp. 2864-2871, 2005.

[8] A. Khalid, "Use of student generated videos to enhance teaching quality in aerospace engineering classes," ASEE Southeast Section Conference American Society for Engineering Education, 2014.

[9] K. Mills-Courts and M. R. Amiran, "Metacognition and the use of portfolios," in P. Belanoff and M. Dickson (Eds.) Portfolios process and product. Portsmouth: Boynton/Cook Publishers Heinemann, 1991.

[10] N. E. Perry, "Young children's self-regulated learning and contexts that support it," Journal of Educational Psychology, vol. 90, pp. 715729, 1998.

[11] D. Parker, "Show us a story: An overview of recent research and resource development work at the British Film Institute," English in Education, vol. 36, no. 1, pp. 38-44, 2002.

[12] S. Schuck and M. Kearney, "Students in the director's seat: Teaching and learning across the school curriculum with student-generated video (Research Report)," Retrieved from University of Technology, Sydney, Teacher Learning and Development Research Group, 2004.

[13] S. C. Wibawa, "Creative Industry Collaboration for the Creative Portfolio," Proceeding International Conference on Creative Industry (ICCI), pp. 365-368, 2013.

[14] S. C. Wibawa, "Developing Electronic Portfolio for Student in Beauty as Repository Creative Activity," Proceeding Bosaris V, The State University of Surabaya, 2013. 